\title{
INDIVIDUAL SERUM TRIIODOTHYRONINE AND THYROXINE LEVELS IN SEVEN FRESHWATER FISH SPECIES
}

\author{
Alexander ATANASOFF *, Dimitrinka ZAPRYANOVA **, \\ Cigdem URKU *** and Galin NIKOLOV ****
}

* Trakia University, Faculty of Veterinary Medicine, Department of Animal Husbandry, Students Campus 2, Stara Zagora, Bulgaria, BG-6014, hmi_atanasoff@mail.bg, ORCID: 0000-0003-3460-9589.

** Trakia University, Faculty of Veterinary Medicine, Department of Pharmacology, Physiology of the Animals and Physiological Chemistry, Students Campus 2, Stara Zagora, Bulgaria, BG-6014, zaprianowa@abv.bg, ORCID: 0000-0002-0430-1690.

*** Istanbul University, Faculty of Aquatic Science, Department of Aquaculture and Fish Diseases, Ordu Street 200, Istanbul, Turkey, TR-34134, curku@istanbul.edu.tr, ORCID: 0000-0003-0381-9321.

**** Trakia University, Faculty of Agriculture, Department of Biology and Aquaculutre, Students Campus 2, Stara Zagora, Bulgaria, BG-6014, galin_goldfish@abv.bg, ORCID: 0000-0001-8920-7435.

DOI: $10.2478 /$ trser-2021-0004

KEYWORDS: Acipenseridae, Clariidae, Cyprinidae, Salmonidae, thyroid hormones.

\section{ABSTRACT}

The thyroid hormones (THs) play an important role in the regulation of the rate of metabolism, affect the growth and function of different systems in the organism. The aim of this study was to assess serum concentration of total triiodothyronine (T3), total thyroxine (T4) as well as T3/T4 ratio in serum from healthy fresh water fish from Salmonidae, Acipenseridae, Cyprinidae, and Clariidae families to determine species-specific reference intervals. Mean concentrations of T3 and T4 levels varied significantly among fish. Finally, the test results show clear differences in the serum concentration of the T3 and T4 and give new insight into the thyroid hormones reference values in some commercial fresh water fish species.

RÉSUMÉ: Taux sériques individuels de triiodothyronine et de thyroxine dans quatre familles de poissons d'eau douce.

Les hormones thyroïdiennes (TH) jouent un rôle important dans la régulation du taux de métabolisme, affectent la croissance et le fonctionnement des différents systèmes de l'organisme. Le but de cette étude était d'évaluer la concentration sérique de la triiodothyronine totale(T3), de la thyroxine totale (T4) ainsi que le rapport T3/T4 dans le sérum des poissons d'eau douce sains d'Salmonidae, Acipenseridae, Cyprinidae, and Clariidae afin de déterminer les intervalles de référence spécifiques à chaque espèce. Les concentrations moyennes des niveaux de T3 et T4 ont varié significative parmi les poissons. Enfin, les résultats des tests montrent de nettes différences dans la concentration sérique de la T3 et T4, et donnent un nouvel aperçu des valeurs de référence des hormones thyroïdiennes chez certaines espèces commerciales de poissons d'eau douce.

REZUMAT: Nivelurile serice individuale de triiodotironă şi tiroxină în patru familii de pești de apă dulce.

Hormonii tiroidieni (TH) joacă un rol important în reglarea ratei metabolismului, afectând creșterea și funcționarea diferitelor sisteme din organism. Scopul acestui studiu a fost de a evalua concentrația serică de triiodotironină totală (T3), tiroxină totală (T4), precum şi raportul T3/T4 în ser de pește sănătos de apă dulce de la Salmonidae, Acipenseridae, Cyprinidae şi Clariidae, a determina intervalele de referință specifice speciei. Concentrațiile medii ale nivelurilor T3 şi T4 au variat semnificativ în rândul peștilor. În cele din urmă, rezultatele testelor arată diferențe clare în concentrația serică a T3 și T4 și oferă o nouă perspectivă asupra valorilor de referință ale hormonilor tiroidieni la unele specii comerciale de pești de apă dulce. 


\section{INTRODUCTION}

The levels for some enzymes, hormones, and ions can be used as indicators of health for different animal species as well as fish. Endocrine parameters can be useful as indicators for physiological and pathological processes in the body of fish. The major hormonal determinations carried out on the fish are for cortisol, progesterone, insulin, and thyroxine (Labarrère et al., 2013). The pro-hormone thyroxine (T4) and small amount of the biologically active hormone triiodothyronine (T3) are synthesized by the thyroid follicles (Krassas et al., 2007). The liver is the major organ responsible for conversion of thyroxine to triiodothyronine, synthesis of thyroid binding globulin (TBG), as well as release of T3 and T4 into the circulation (Neto and Zantut-Wittmann, 2016).

Despite over a decade of research, the role of the thyroid hormones in fish is still not fully understood, because the diffuse structure of the thyroid glands making it more difficult to study (van de Pol et al., 2017; Campinho, 2019). They also, have unique characteristics and functions due to diversity in fish anatomy, habitat, and life cycle (Deal and Volkoff, 2020). Furthermore, some studies have reported positive effects of thyroid hormones to improve hatching, post-embryonic growth, and larval survival (Stepien and Huttner, 2019; Deal and Volkoff, 2020). Also, thyroid hormones play a significant role in almost all physiological processes in the body (i.e. metabolic process, bone remodeling, cardiac function, mental state, and brain development) (Singh et al., 2014; Gavrilă and Hollenberg, 2019). Therefore, a better understanding of function and structure of thyroid hormones can provide valuable information to improve the knowledge about the freshwater fish species physiology.

The present study aimed to establish referent values of total triiodothyronine and total thyroxine, using as model some typical representatives of four freshwater fish families (Salmonidae, Acipenseridae, Cyprinidae, and Clariidae).

An additional purpose of this work is to add the information in the existing database which is used to monitor fish health.

\section{MATERIAL AND METHODS}

The study was done in the spring season (April, 2019) on fish individuals belonging to Salmonidae, Acipenseridae, Cyprinidae, and Clariidae families. Totally 120 fish (12 fish individuals per species) for analyses were collected from different fish production systems, as follows Brown trout-Salmo trutta fario Linnaeus, 1758 and Rainbow trout-Oncorhynchus mykiss (Walbaum, 1792) - concrete tanks and net cages; Common carp-Cyprinus carpio Linnaeus, 1758 - ponds and net cages; Russian sturgeon-Acipenser gueldenstaedtii Brandt and Ratzeburg, 1833, Siberian sturgeon-Acipenser baerii Brandt, 1869, and hybrids - net cages only and African catfish-Clarias gariepinus (Burchell, 1822), recirculation system.

Blood samples were drawn from the vena caudalis using a needle (20G). The collected samples (approx. one ml) have been centrifuged at 3,000 rpm for five minutes (Ohaus FC5515, Ohaus Corp., USA) at room temperature. After coagulation, the obtained serum was immediately separated and it was stored at $-20^{\circ} \mathrm{C}$ until analysis. Total triiodothyronine and total thyroxine analyses were conducted with Elisa analyser, HumaReader HS (Human GmbH, Wiesbaden, Germany) and its measurement Elisa kit (Monobind, Inc., USA).

Descriptive statistical analyses for calculating the means and the standard error of the mean were performed using the StatSoft Statistica v.10 software (StatSoft Inc., USA, 2002). All the results obtained were expressed as the mean \pm standard error (SE). 


\section{RESULTS AND DISCUSSION}

A study of species-specific differences in total triiodothyronine and total thyroxine in representatives of four fish families could help future scientists assess the health of the fish. The acquired results are shown in figures 1-3.

The variations were observed in the serum levels of both thyroid hormones in all studied species. Data regarding level of total triiodothyronine (Fig. 1) show obvious differences between families and individual species the biggest being between Clarias gariepinus $(0.806 \mathrm{ng} / \mathrm{ml})$ and Acipenser gueldenstaedtii $(4.49 \mathrm{ng} / \mathrm{ml})$. Median total thyroxine concentrations were highest in sturgeon species and show major differences against the other species as follow: Salmo trutta fario $(1.31 \pm 0.09 \mu \mathrm{g} / \mathrm{dL})$; common carp $(1.80 \pm 0.23 \mu \mathrm{g} / \mathrm{dL})$ and Clarias gariepinus $(1.67 \pm 0.16 \mu \mathrm{g} / \mathrm{dL})$ and non differences between acipenserids (Acipenser baerii - $3.15 \mu \mathrm{g} / \mathrm{dL}$ and Acipenser gueldenstaedtii - $5.33 \mu \mathrm{g} / \mathrm{dL}$ ). Furthermore, to individual levels for $\mathrm{T} 3$ and $\mathrm{T} 4$, ratios of $\mathrm{T} 3 / \mathrm{T} 4$ concentrations were calculated for each species. Determined ratios of T3/T4 were around 0.6 in a majority of studied species whereas in Salmo trutta fario and Cyprinus carpio were 1.45 and 1.44, respectively.

The study was conducted in spring season because the thyroid hormones activity increased significantly from January to April and decreased significantly during autumn and early winter from October to December according to decrease of water temperature. Not only the season and water temperature have a severe impact on hormone activity but also important are biotic factors such as health condition, husbandry of fish, feed and technology system, environment. By hormones fish can adapt to constantly changing environment. Like other vertebrates, teleost fish also use the hypothalamic-pituitary-thyroid (HPT) axis to regulate their metabolism. The central nervous system, provoked by the diverse environment, regulates the homeostasis of thyroid hormones. In vertebrates the follicles are aggregated into one or two thyroid glands while in teleost fish, thyroid gland is scattered elements (follicles) around the ventral aorta. In them, thyrotropin-releasing hormone (TRH) stimulates the anterior pituitary to synthesize and secrete the thyroid-stimulating hormone (TSH), but there is an assumption that TRH is not a major TSH-releasing factor in fish (Cortés et al., 2014). Also, TSH take part in formation and production of thyroid hormones which are 3, 3', 5-Triiodo-L-thyronine (triiodothyronine, T3), and L-thyroxine (thyroxine, T4) which have negative feedback regulating effect on TSH (Fig. 4). The thyroid gland is the only endocrine organ with such an extracellular store (follicular) where T3 and T4 are stored (Qu et al., 2016).

Thyroid function in fish has been investigated mainly on teleost fish of the class Actinopterygii, subclass Chondrosteii which include order Acipenseriformes to this the sturgeons belong (Plohman et al., 2002). Most early studies of sturgeon thyroid were on Acipenser stellatus and Acipenser gueldenstaedtii (McKenzie et al., 2007). Authors observed much higher percentages of free T4 and T3 present in sturgeon plasma than in Oncorhynchus mykiss used like a model for comparing. Plohman et al., (2002) also observed significant differences in thyroid hormone concentrations in blood plasma and tissues during immature-phase and spawning-phase of lake sturgeon-Acipenser fulvescens compared with some teleost fish. Authors had proposed that in the sturgeon, manufacture of triiodothyronine is main determined of releasing process in peripheral tissues. Indeed, the comparison of the results shows that the levels of thyroxine in Acipenser gueldenstaedtii and Acipenser baerii were much higher than other fish species subject to this study. It should also be noted that the concentration of triiodothyronine in Acipenser gueldenstaedtii was highest in current study. 


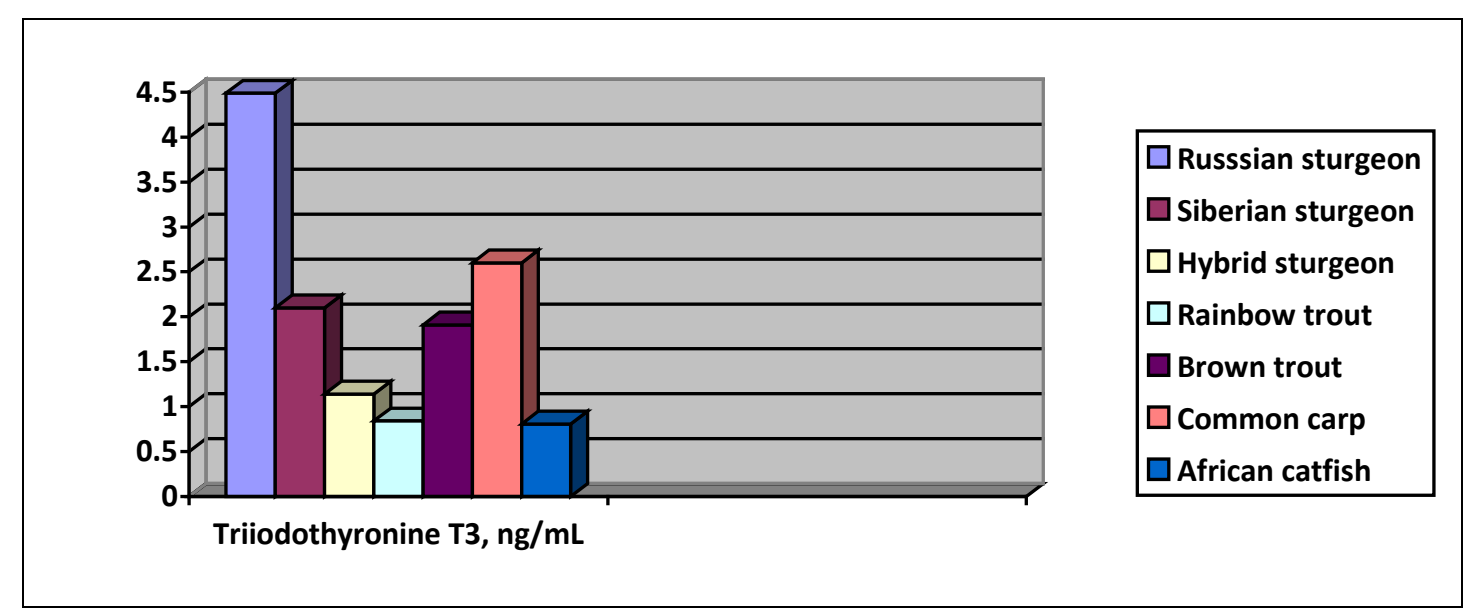

Figure 1: Levels of triiodothyronine (T3) ng/mL

of representatives of Salmonidae, Acipenseridae, Cyprinidae, and Clariidae family.

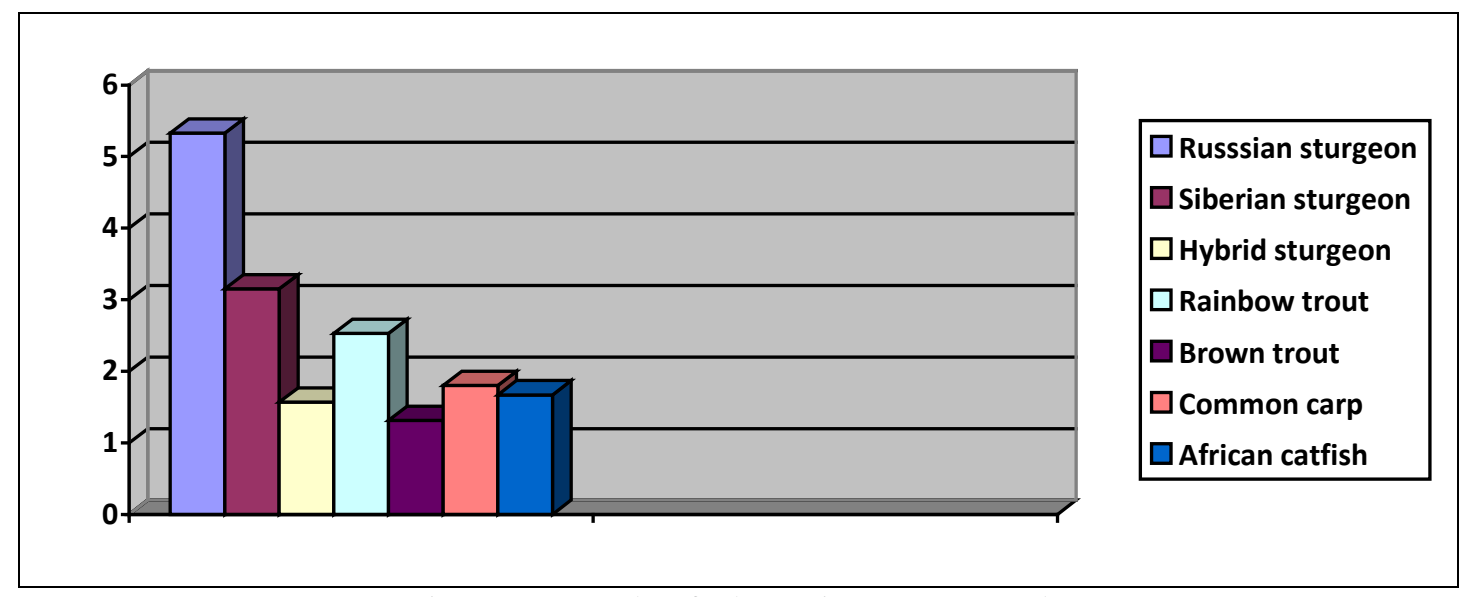

Figure 2: Levels of Thyroxine (T4) mcg/dL

of representatives of Salmonidae, Acipenseridae, Cyprinidae, and Clariidae family.

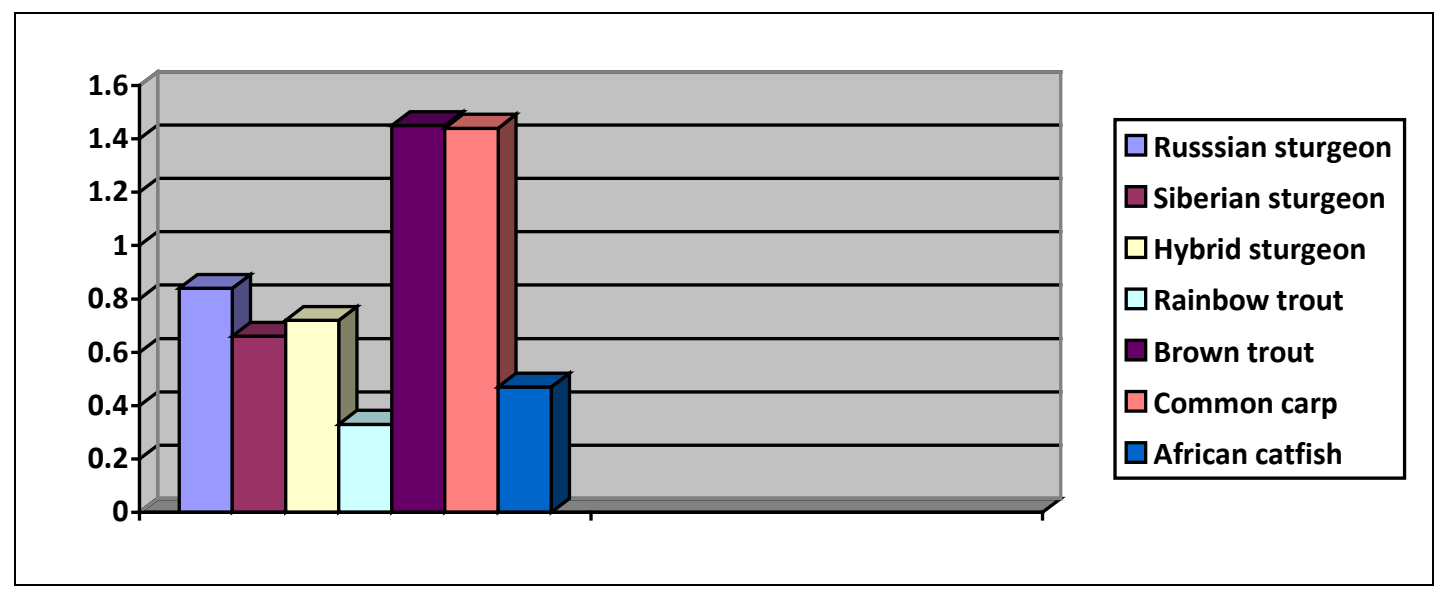

Figure 3: Levels of T3/T4 ration

of representatives of Salmonidae, Acipenseridae, Cyprinidae, and Clariidae family. 


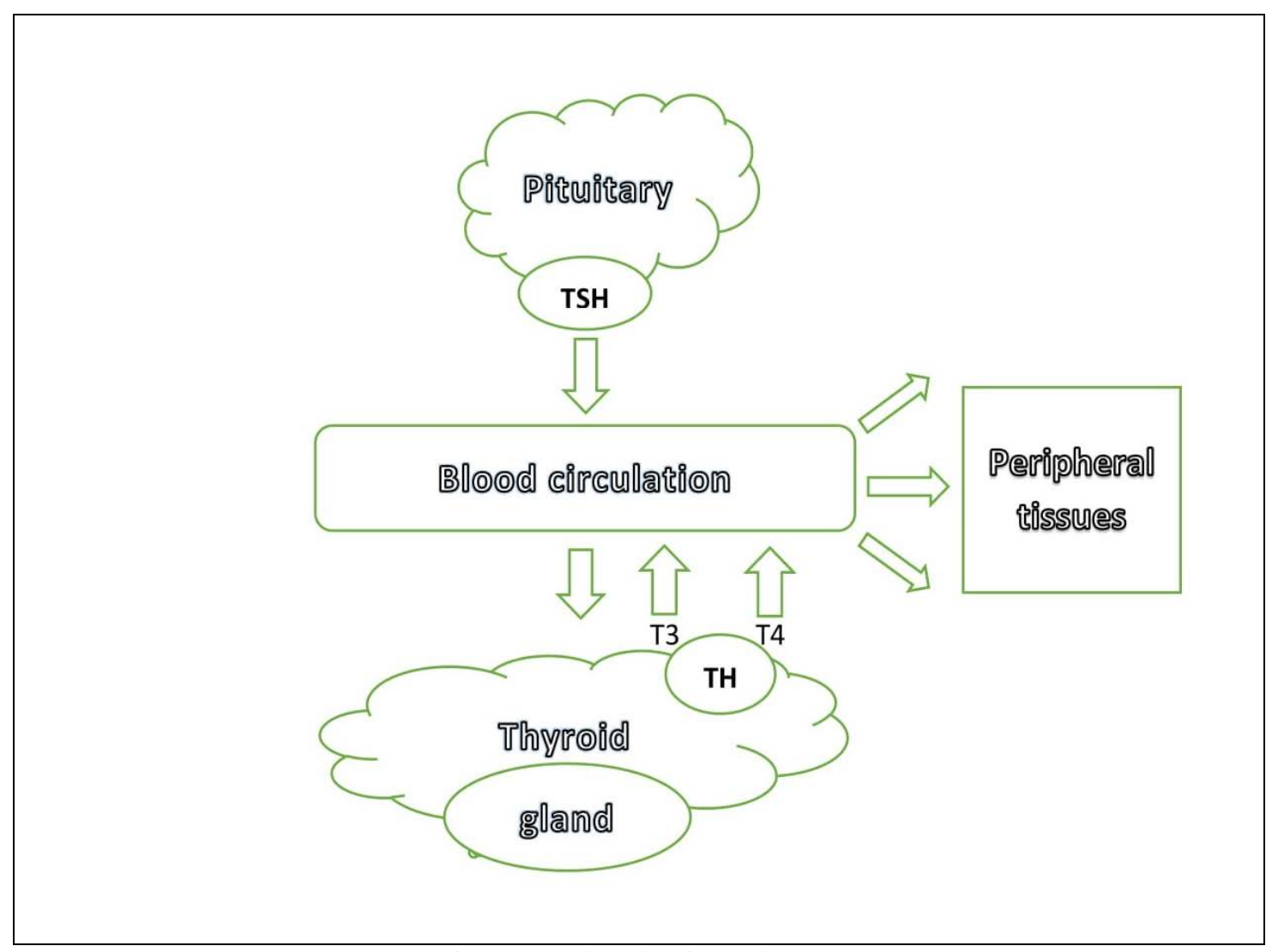

Figure 4: The classic pathways of thyroid hormone metabolism.

According to the obtained results by Gomez et al. (1997) in Oncorhynchus mykiss the baseline levels of T3 are $2.2 \pm 0.2 \mathrm{ng} / \mathrm{ml}$, as well as the average daily T3 concentration is $2.6 \pm$ $0.2 \mathrm{ng} / \mathrm{ml}$ (range 0.6 to $7.1 \mathrm{ng} / \mathrm{ml}$ ) which were not close to the values obtained by us. The authors reveal a high degree of variability in the magnitude of T4 peaks (range 0.8 to 12.7 $\mathrm{ng} / \mathrm{ml}$ ) and the average daily T3/T4 $=0.5$ while in our study the ratio is lower (0.33). Authors based its conclusions on absolute plasma T3 and T4 concentrations that fluctuations of T3/T4 ratio depend on the type of observations and on the time scale. Their results support theory of separate regulation of $\mathrm{T} 3$ and $\mathrm{T} 4$ production under normal physiological conditions. Recognising the limitations of our analysis, we attributed the low levels of T3 to feed. Oncorhynchus mykiss fed a high-fat diet reduced plasma T3 level, while the same diet resulted in high plasma T4 level and hence to reduce T3/T4 ratio.

The study therefore established that mean T4 concentration in Cyprinus carpio was $1.80 \mu \mathrm{g} / \mathrm{dl}$, which was similar to levels in cyprinid fish reported by Dogru et al. (2016). In terms of T3, the levels indicated by the same authors were much higher than our results. The results of the current study generally were similar to results observed in studies by Dapeng et al. (2008) conducted with healthy crucian carp-Carassius auratus (Linnaeus, 1758), where the triiodothyronine concentration in the blood is $1.84 \mathrm{ng} / \mathrm{ml}$ and thyroxine $11.08 \mathrm{ng} / \mathrm{ml}$. In the current study, where Cyprinus carpio under growth in net cages and ponds conditions, it can be concluded that season and spawning period that the cause of the variation in TH levels. 
The results revealed significant differences when Clarias gariepinus were compared with other fish species. In a Clarias gariepinus the values were lowest in comparison to another in the study. The T3 concentrations determined in current study were close to the mean values reported by Ahmed et al. (2015) $(1.58 \mathrm{ng} / \mathrm{ml})$, as well as were the similar $(0.54 \mathrm{ng} / \mathrm{ml})$ reported by Suchiang and Gupta (2011) for summer period.

Additionally, we have to take into account the fact that the cause of the differences in blood parameters could be species-specific variations, different environmental conditions and health status (Nicula et al., 2010).

\section{CONCLUSIONS}

The present study was designed to determine serum thyroid hormone concentrations in fish species which belong to four families and represent important species for aquaculture. It can be concluded that contributes to detailed description of the mean levels of triiodothyronine and thyroxine in seven freshwater fishes during the spring season. However, the data are insufficient, and more research is needed to complete the hormonal profile and identified relationships with other hormones and different conditions.

\section{ACKNOWLEDGEMENTS}

This trial would not have been possible without the active cooperation of many persons and fish farms, we are deeply obliged to them. Our research team would like to thank Dr. Sinan Kandir, Cukurova University, Faculty of Ceyhan Veterinary Medicine, Turkey, for useful discussions and constructive criticism. 


\section{REFERENCES}

1. Ahmed T., Ibrahim Ahmed A. and Harabawy S. A., 2015 - The ability of vitamin E, selenium and water to improve and recover the hematological, biochemical and hormonal parameters of mercury-exposed catfish Clarias gariepinus (Burchell, 1822), Egyptian Academic Journal of Biological Sciences, B., Zoology, 7, 2, 1-19.

2. Suchiang P. and Gupta B. B. P., 2011 - Variations in the plasma levels of thyroid hormones and testicular activity in the male air-breathing catfish (Clarias gariepinus) over the annual cycle, International Journal of Biology, 3, 3, 144-155.

3. Campinho M., 2019 - Teleost metamorphosis: the role of thyroid hormone, Frontiers in Endocrinology, 10, 383.

4. $\quad$ Dapeng L., Ping X. and Xuezhen Z., 2008 - Changes in plasma thyroid hormones and cortisol levels in crucian carp (Carassius auratus) exposed to the extracted microcystins, Chemosphere, 74, 13-18.

5. Deal C., and Volkoff H., 2020 - The role of the thyroid axis in fish, Frontiers in Endocrinology, 11, 596585.

6. McKenzie D., Anthony P. and Colin J., 2007 - Fish physiology: primitive fishes, 26, $1^{\text {st }}$ edit., Academic Press, 576.

7. Gavrilă A. and Hollenberg A., 2019 - The hypothalamic-pituitary-thyroid axis: physiological regulation and clinical implications, in Luster M., Duntas L. and Wartofsky L. (eds), The thyroid and its diseases, Chamonix, CH, Springer, 13-23.

8. Dogru M., Polat H., Erdogan K., Dogru A., Kandemir S., Orun G., Yilmaz S., Akgul H. and Orun I., 2016 - Effects of rosehip extracts on common carp (Cyprinus carpio) TSH and thyroid gland activity, Fresenius Environmental Bulletin, 25, 1, 4708-4713.

9. Gomez J., Boujard T., Boeuf G., Solari A. and Le Bail Y., 1997 - Individual diurnal plasma profiles of thyroid hormones in rainbow trout (Oncorhynchus mykiss) in relation to cortisol, growth hormone, and growth rate, General and Comparative Endocrinology, 107, 74-83.

10. Jiang-qi Qu., Cheng-xia J., Pan L., Mu Y. and Qing-jing Z., 2016 - The levels of serum thyroid hormone in sturgeon populations, International Proceedings of Chemical, Biological and Environmental Engineering, 95, 3, 14-18.

11. Krassas G., Rivkees S. and Kiess W., 2007 - Diseases of the thyroid in childhood and adolescence, Pediatric and Adolescent Medicine, Basel, Karger, 11, 80-103.

12. Labarrère C., Carvalho de Faria P., Edgar de Alencar T. and Melo M., 2013 - Blood chemistry profile of surubim hybrid fish (Pseudoplatystoma Reticulatum X Pseudoplatystoma Corruscans) raised in different stocking densities, Ciência e Agrotecnologia, 37, 3, 251-258.

13. Neto A. and Zantut-Wittmann D., 2016 - Abnormalities of thyroid hormone metabolism during systemic illness: the low T3 syndrome in different clinical settings, International Journal of Endocrinology, 3, 1-9.

14. Nicula M., Bura M., Simiz E., Bănăţean-Dunea I., Pătruică S., Marcu A., Lunca M. and Szelei Z., 2010 - Researches concerning reference values assessment of serum biochemical parameters in some fish species from Acipenseridae, Cyprinidae, Esocidae and Salmonidae family, Animal Science and Biotechnologies, 43, 1, 498-505.

15. Plohman J., Dick T. and Eales J., 2002 - Thyroid of lake sturgeon, Acipenser fulvescens, I, Hormone levels in blood and tissues, General and Comparative Endocrinology, 125, 47-55.

16. Stepien B. and Huttner W., 2019 - Transport, metabolism, and function of thyroid hormones in the developing mammalian brain, Frontiers in Endocrinology, 10, 209.

17. Singh A., Fridman Y., Friedlander-Shani L., Tarkowska D., Strnad M. and Savaldi-Goldstein S., 2014 - Activity of the Brassinosteroid transcription factors Brassionazole resistant1 and Brassinosteroid intensitive1-ethyl-methansulfonate-suppressor1/Brassinazole resistant2 blocks developmental reprogramming in response to low phosphate availability, Plant Physiology, 166, 2, 678-688. 
18. Van de Pol I., Flik G. and Gorissen M., 2017 - Comparative physiology of energy metabolism: fishing for endocrine signals in the early vertebrate pool, Frontiers in Endocrinology, 8, 36. 